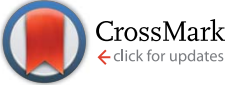

Cite this: RSC Adv., 2017, 7, 3941

Received 6th November 2016

Accepted 28th November 2016

DOI: $10.1039 / \mathrm{c} 6 \mathrm{ra} 26379 \mathrm{~h}$

www.rsc.org/advances

\title{
Bacterial iron-oxide nanowires from biofilm waste as a new adsorbent for the removal of arsenic from water $\dagger$
}

\author{
Ivan Andjelkovic, ${ }^{\text {ab }}$ Sara Azari, ${ }^{a}$ Mason Erkelens, ${ }^{a}$ Peter Forward, ${ }^{c}$ Martin F. Lambert ${ }^{\star d}$ \\ and Dusan Losic*a
}

Biofilm, generated by the bacteria in the groundwater pumping system pipelines of the Salt Interception Scheme on the River Murray in South Australia is discarded as a waste material accumulated after periodic cleaning of the pipes. Structural and chemical composition characterizations confirm that this waste material is composed of amorphous twisted iron-oxide nanowires (ION), generated by bacteria, and they have a unique structure and properties. The adsorption performance of these iron-oxide nanowires for arsenic removal from water was evaluated to define their adsorption capacity for As(III) and As(v) and kinetics. Obtained results demonstrate considerable adsorption properties of this waste biological material and suggest its promising application as a new and low-cost adsorbent for water treatment.
\end{abstract}

\section{Introduction}

High concentrations of arsenic in drinking water pose the biggest environmental problem today, affecting more than 150 million people only in the region of West Bengal and Bangladesh. ${ }^{1,2}$ The estimation of some experts is that as many as 500 million people could be affected by this problem worldwide. Arsenic is genotoxic, ${ }^{3}$ cytotoxic $^{4}$ and a well-known human carcinogen. ${ }^{5}$ Exposure to high levels of arsenic also induces epidemiological toxicity, damaging organisms by producing reactive oxygen species. ${ }^{6}$ Even though values below $10 \mu \mathrm{g} \mathrm{\textrm {L } ^ { - 1 }}$ have been recommended as the safe values for arsenic in drinking water by the United Nations Children's Fund (UNICEF) and the World Health Organization (WHO), recent studies demonstrated that even concentrations below this value are still harmful to human health., ${ }^{7,8}$ Because most of the higher concentrations of arsenic in natural waters are not caused by human activity but are the consequence of natural processes, it is not possible to control the pollution but we can undertake the remediation of contaminated water., ${ }^{2,9}$ Diversity of matrix in which arsenic is present coupled with different initial

${ }^{a}$ School of Chemical Engineering, University of Adelaide, Adelaide, SA, 5005, Australia. E-mail: dusan.losic@adelaide.edu.au

${ }^{b}$ Innovation Center of the Faculty of Chemistry, University of Belgrade, Studentski Trg 12-16, Belgrade, Serbia

${ }^{c}$ SA Water, South Australia, 5005, Australia

${ }^{d}$ School of Civil, Environmental and Mining Engineering, University of Adelaide, Adelaide, SA, 5005, Australia. E-mail: martin.lambert@adelaiude.edu.au

† Electronic supplementary information (ESI) available. See DOI: $10.1039 / \mathrm{c} 6 \mathrm{ra} 26379 \mathrm{~h}$ concentrations of arsenic and limited availability of technologies and materials for arsenic treatment is the reason why scientists still trying working on the problem of arsenic removal from drinking water. High concentrations of arsenic in waters in various regions of the world, verify the demand for an economical effective, and reliable technique that is capable of removing arsenic species to the accepted level.

Until now many water treatment technologies including reverse osmosis, chemical coagulation, filtration, and adsorptions have been explored and practically implemented for arsenic removal in different areas of the world. Among them the adsorption processes using adsorbents because of their easy to setup, low-costs and potentially lower chemical and energy requirements as well less environmental impacts are regarded as the most attractive. Many adsorbents based on synthetic oxides including synthetic birnessite, ${ }^{10}$ nanocrystalline $\mathrm{TiO}_{2},{ }^{11}$ iron-oxide nanoparticles and nanosheets, ${ }^{\mathbf{1 2 - 1 4}}$ activated alumina, ${ }^{15} \mathrm{ZrO}_{2}$ and $\mathrm{NiO}$ nanopowders ${ }^{12}$ and $\mathrm{CuO}$ nanoparticles $^{\mathbf{1 6}}$ have been explored in past 20-30 years. All mentioned adsorbents have various limitations regarding their application in removal of arsenic such as: low adsorption capacity, narrow range of optimal $\mathrm{pH}$ for effective removal, selectivity of adsorption for some arsenic species, necessity of removal of competing ions from source water (e.g. phosphate, silicate, sulphate), scalability and sustainability of their production. Composite materials that contain metal oxides, such as graphene- $\mathrm{Fe}_{3} \mathrm{O}_{4}$ nanocomposite, ${ }^{17,18}$ laterite-polyacrylonitrile and aluminium oxyhydroxide-poly[(4-vinylbenzyl) trimethylammonium chloride $]^{19}$ were explored to address some of these limitations. The unavailability of technology for their synthesis coupled with high cost of these composites 
limits their broad use in developing countries especially and highly populated regions with high As pollution of underground water. To address these limitations the development of new and low-cost adsorbents is required where natural materials are recognized as the best choice.

Iron minerals are one of the most examined natural materials for arsenic adsorption because of their availability and high affinity towards arsenic. ${ }^{2,20}$ One example of is iron-oxide coated sand which a low cost but showed to have poor adsorption capacity for removal of $\mathrm{As}(\mathrm{III})$ and $\mathrm{As}(\mathrm{v})$ species mainly due low surface area. ${ }^{21}$ In recent years, continuous efforts have been made on the preparation of the threedimensional hierarchically nanostructured materials, based on iron oxides, which shows enhanced properties compared to their bulk counterparts, like 3D flower like $\alpha-\mathrm{Fe}_{2} \mathrm{O}_{3}$, chestnut like $\gamma-\mathrm{Fe}_{2} \mathrm{O}_{3}$ and urchin like $\alpha$-FeOOH. ${ }^{22-24}$ Even though the cost of starting material is very low, heat treatment is used in preparation of material, increasing the price of adsorbent and giving adsorption capacity way below that achieved with other synthetic adsorbents. Recently, iron mineral samples, goethite, magnetite, hematite and laterite were used as simple, affordable and readily available materials for household removal of arsenic from drinking water. ${ }^{25}$ The showed good performance to remove $\mathrm{As}(\mathrm{v})$ from water using very high adsorbent dosages which creates the problem of a large waste for disposal. However, there are some problems with these methods because of their scalability, high-cost, sustainability and large environmental footprints as they use toxic materials and lead to the generation of toxic chemical waste.

In this paper we present for the first time the application of waste bacteria biofilm as new adsorbent for As removal from water. It is well known that some living organisms such bacteria and fungi have acquired the ability to produce biogenic metallic and metal oxide nanostructures with intricate designs and precisely controlled morphologies and dimensions. One examples are creation of long and helical iron(II) encrusted nanowires are produced by the zetaproteobacteria, Mariprofundus ferrooxydans in an iron abundant environment. ${ }^{26-28}$ Recently, we discovered that the bacterial biofilm that clog the pipelines and pumps of the Salt Interception Scheme (SIS) in South Australia is composed of these unique iron-oxide nanowires. This biofilm is a huge problem to maintain in this $28 \mathrm{~km}$ long pipeline system and requires continues labor intensive and costly removal and cleaning. During last 10 years significant deposits (hundreds of tonnes) of this waste materials are stored as waste in surrounding environment. In our recent work we found this iron-oxide nanowires have photocatalytic and magnetic properties and demonstrate their applications for photocatalytic degradation of organic pollutants and drug delivery with hypothermia based treatment of cancer. ${ }^{\mathbf{2 9}, 30}$ The aim of this work is to investigate the adsorption properties of this material available in large quantities as biofilm waste as an adsorbent for removal of arsenic from drinking or environmental water. The properties including adsorption capacity, absorbance kinetics, $\mathrm{pH}$ dependence and influence of interference of other ions were determined. Obtained results indicate that this waste material can be successfully applied as an efficient and low cost adsorbent to address many environmental problems including removing heavy metals, phosphates and organic compounds from contaminated waters and used for soil remediation.

\section{Materials and methods}

\section{Materials and chemicals}

The biofilm samples were obtained directly from the pipeline system in the Woolpunda Salt Interception Scheme on the River Murray in South Australia. For this work samples from Bore 24 were collected from the pipe cleaning waste dump and scraping small amounts from the outlet pipe from the pump. The iron-oxide nanowires were separated by purification of bacterial biofilm samples through several filtration and rinsing steps to remove salt and organic impurities. The purified iron-oxide material is dried at $80-100{ }^{\circ} \mathrm{C}$ and stored before use. Arsenite and arsenate stock solutions f1000 mg $\mathrm{L}^{-1}$ ) were prepared by dissolving an appropriate amount of $\mathrm{NaAsO}_{2}$ and $\mathrm{Na}_{2} \mathrm{HAsO}_{4} \cdot 7 \mathrm{H}_{2} \mathrm{O}$ obtained from Sigma Aldrich (Australia, Sydney) in deionized water (DI), respectively. Highpurity Milli-Q water $\left(18.2 \mathrm{M} \Omega \mathrm{cm}\right.$ at $25{ }^{\circ} \mathrm{C}$, pH of 5.6) was used throughout the study, unless otherwise stated.

\section{Characterizations}

The characterization of bacterial biofilm and morphology of the iron-oxide structures before and after purifications was performed by scanning electron microscope (FE-SEM, Quanta 450, FEI, USA). A drop of their water dispersion was placed onto $\mathrm{Si}$ substrate and dried followed by coating thin Pt film.

Fourier transform infrared (FTIR) spectroscopy (Spectrum 100, Perkin Elmer, USA) was used to identify the functional groups of the iron-oxide nanowires samples before and after adsorption of arsenic species, in the range of $550-3050 \mathrm{~cm}^{-1}$ in transmission mode. The X-ray diffraction (XRD, Miniflex 600, Rigaku, Japan) measurement was performed from $2 \theta=20-80^{\circ}$ to illuminate the composition of the iron oxide nanowires at a scan rate of $5^{\circ} \mathrm{min}^{-1}$. The specific surface area (SSA) of the iron nanowires was determined using the BET surface area analysis (Belsorp, Japan). The zeta potential of the wires was measured with a Malvern Zetasizer (Nanoseries, Australia) as a function of $\mathrm{pH}$. The $\mathrm{pH}$ of the mixture was adjusted with either $\mathrm{HCl}$ or $\mathrm{NaOH}$ from 3 to 10 . The measurements were performed in triplicate and data are presented as an average.

\section{Adsorption capacity of iron oxide nanowires for As}

Batch adsorption tests were carried out, individually for As(III) and $\mathrm{As}(\mathrm{v})$, to examine effect of contact time, effect of $\mathrm{pH}$ on adsorption and to determine adsorption capacity of adsorbent. Experiments were done in $50 \mathrm{~mL}$ plastic flasks with $10 \mathrm{mg}$ of adsorbent and $25 \mathrm{~mL}$ of arsenic solution in DI water at room temperature $\left(22{ }^{\circ} \mathrm{C} \pm 1\right)$ at $250 \mathrm{rpm}$ in a shaker (OM7 Ratek Instruments, Australia).

For kinetic experiments, $10 \mathrm{mg} \mathrm{L}^{-1}$ arsenic solutions with initial pH 7, were mixed for 5, 10, 15, 20, 30, 45, 60, 90 and 120 minutes. After the end of specified contact time the suspensions were immediately filtered through $0.22 \mu \mathrm{m}$ Teflon filter and 
arsenic concentrations were measured with ICP-MS (7500 cs Agilent Technologies, USA).

The effect of $\mathrm{pH}$ on arsenic adsorption was examined in $\mathrm{pH}$ range $3-10$. Initial $\mathrm{pH}$ of $10 \mathrm{mg} \mathrm{L}^{-1}$ arsenic solution was adjusted using diluted hydrochloric acid or sodium hydroxide solution. After the addition of sorbent solutions were mixed for 120 minutes and suspensions were immediately filtered through $0.22 \mu \mathrm{m}$ Teflon filter and the filtrates were analysed. Isotherm studies were carried out at initial $\mathrm{pH} 3$ and 9 for $\mathrm{As}(\mathrm{v})$ and As(III), respectively. Experiments were performed by mixing different concentrations of $\mathrm{As}(\mathrm{V})$ and $\mathrm{As}(\mathrm{III})$ with constant dose of adsorbent $\left(0.4 \mathrm{~g} \mathrm{~L}^{-1}\right)$ for 120 minutes. The concentrations of arsenic were in the range of 10 to $50 \mathrm{mg} \mathrm{L}^{-1}$.

In order to investigate influence of co-existing ions on the removal of arsenic, batch experiments with the presence of $\mathrm{PO}_{4}{ }^{3-}, \mathrm{SO}_{4}{ }^{2-}, \mathrm{NO}_{3}{ }^{-}$or $\mathrm{HCO}_{3}{ }^{-}$in the concentration range from 0.1 to $10 \mathrm{mM}$, were done. Dosage of the sorbent was $0.4 / \mathrm{L}$, initial concentration of arsenic was $5 \mathrm{mg} \mathrm{L}^{-1}$ and $\mathrm{pH}$ was adjusted to 7 with the addition of $\mathrm{HCl}$ or $\mathrm{NaOH}$ solutions. Suspensions were shaken for $120 \mathrm{~min}$ at the room temperature and after filtration arsenic in solution was measured with ICP-MS.

\section{Results and discussion}

\section{Structural and chemical characterization of bacterial iron- oxide nanowires obtain from biofilm waste}

The Fig. 1a presents photos of a pipeline with brown biofilm inside the pipe which causes head loss and eventually clogs the pipes and requires regular removal by pipe cleaning using the pigging process (Fig. 1b). The typical morphology of collected biofilm waste obtained from cleaned pipes shows a dense network of wire like structure is presented in Fig. 1c. SEM images of iron-oxide nanowire obtained from purified are presented in Fig. 2a-d showing their unique twisted structures with more details. The SEM images (Fig. 2e and f) of fresh biofilm material revealed interconnected iron-oxide nanowires with bacteria confirming they are produced by bacteria. A single bacteria usually can produce several iron-oxide nanowires (Fig. 2g) that are connected with other bacteria (Fig. 2e). After the purification of biofilm material, bacteria can no longer be seen and structures of iron-oxide nanowires remains with the similar length of nanowires as in starting biofilm. The higher magnification SEM images show twisted, rope-like structure of nanowires, which contributes to mechanical strength of their structures (Fig. 2b-d).
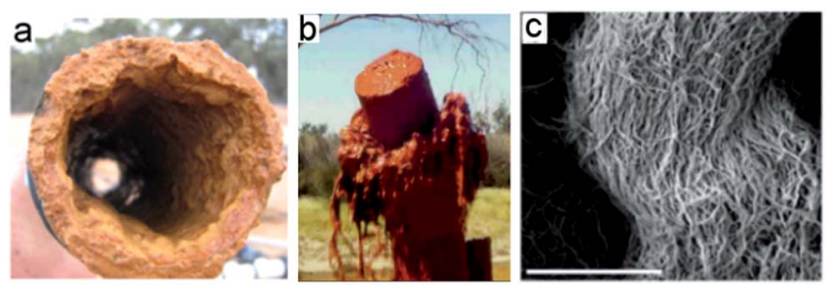

Fig. 1 (a) photo of the inside of a the pipe with the formed bacterial film with (b) cleaning process of biofilm and (c) SEM image of raw bacterial material from the biofilm (scale bar $50 \mu \mathrm{m}$ ).
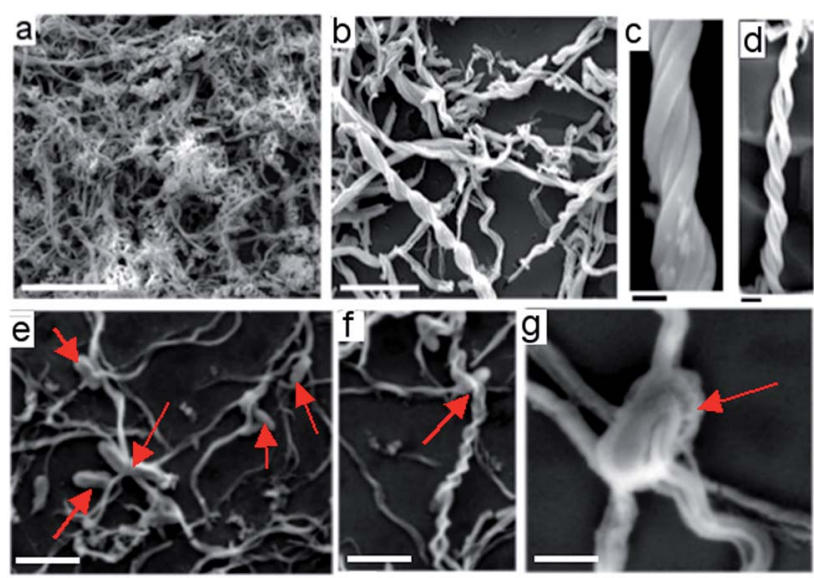

Fig. 2 SEM images of iron-oxide nanowires obtained from waste biofilm after and before purifications. ( $a$ and b) Low resolution images showing network of twisted nanowires (scale bar $20 \mu \mathrm{m}$, and $10 \mu \mathrm{m}$ respectively), (c and d) high resolution SEM images showing helical iron-oxide nanowires bundles. (e and f) SEM images of non purified biofilm sample show bacteria and created nanowires from their body (scale bar $20 \mu \mathrm{m}$, and $5 \mu \mathrm{m}$ respectively), (g) image of single bacteria with created 5 bundles of iron oxide nanowires. (Scale $1 \mu \mathrm{m}$ ).

Typical length of nanowires is from 10-30 microns long and diameter of 100-130 nm with helical and coiled morphology where 4-6 or more wires are bundled together (Fig. $2 \mathrm{c}$ and d).

The mechanism of iron oxide nanowire formation in bacteria biofilms is still not fully understand. Several ironoxidising bacteria species has reported to have capability to produce iron-oxide nanowires including Mariprofundus ferrooxydans which is found in the biofilm used in this work. ${ }^{26-28}$ M. ferrooxydans is a chemolithoautotrophic bacteria that utilises the presence of iron in water solution to produce energy through the oxidation of $\mathrm{Fe}^{2+}$ to $\mathrm{Fe}^{3+}$.

Firstly $M$. ferrooxydans locates an ideal location suitable for $\mathrm{Fe}(\mathrm{II})$ oxidation, once the location has been found $M$. ferroox$y$ dan will attach to the surface and start to produce a stalk as it oxidises iron for the production of energy. During this process the cell will also start dividing, due to this process the stalks become bifurcated and each cell will continue to form individual stalks. When the environment is not ideal for $\mathrm{Fe}^{2+}$ oxidation the cell will detach from the stalk and from a flagellum to locate another ideal location for $\mathrm{Fe}^{2+}$ oxidation. ${ }^{26-28}$ We analysed the genetics of fresh biofilm taken from pipes using $16 \mathrm{~s}$ rRNA gene sequence to determine the bacterial community structure. It was found a total of 21476 sequences with an average sequence length of $446 \mathrm{bp}$, a total of 80 OTU's were detected composed of large numbers of different bacteria mostly by Proteobacteria (96.78\%), the rest of the bacterial community was formed by Actinobacteria, Bacteroidetes, Chlorobi, Chloroflexi, Firmicutes, Gemmatimonadetes, Nitrospirae, Planctomycetes and WS3. Mariprofundus sp. an iron oxidizing bacteria that formed $0.01 \%$ of the bacterial community is found within the iron nanowire biofilm.

The EDX analysis of purified materials confirms that this material consists mostly from iron and oxygen with traces 
amounts of carbon, silicon, calcium and phosphorus (Fig. S1 $\dagger$ ). The absence of peaks in XRD spectra of a purified iron-oxide nanowires shows that our material doesn't have crystal structure and represents pattern typical for amorphous structure (Fig. S2†).

Iron-oxide minerals initially formed in natural waters are usually poorly crystalline and have high surface area which benefits adsorption of arsenic. Although these minerals, over time, depending on the temperature, $\mathrm{pH}$ and other present species, undergo transformations to more crystalline forms these transformations doesn't result in desorption of arsenic. ${ }^{31}$ BET adsorption measurements gave specific surface area of iron-oxide nanowires of $180 \mathrm{~m}^{2} \mathrm{~g}^{-1}$ with the isotherm that can be classified as type I according to IUPAC classification ${ }^{32}$ (Fig. S3 $\dagger$ ). This suggests that most of the surface area of ironoxide nanowires lies within microporous materials. ${ }^{33}$

\section{Adsorption kinetics}

The kinetics of As(III) and As(v) adsorption by iron-oxide nanowires was studied with $5 \mathrm{mg} \mathrm{L}^{-1}$ initial concentration of arsenic at $\mathrm{pH}=7$ and results are presented in Fig. 3. Two conclusions can be derived from Fig. 3: (1) kinetic of adsorption of both arsenic species was very fast achieving equilibrium after $2 \mathrm{~h}$ of contact time; (2) removal efficiency of iron-oxide nanowires, at pH 7, was better for As(v) than As(III). Rapid initial adsorption could be explained with high specific surface area and easy available active adsorption sites at the surface of iron-oxide nanowires which are first occupied. After initial fast adsorption during first 20 minutes, arsenic species diffuse through liquid film at the surface of adsorbent and further through narrow pore channels of iron-oxide nanowires which slows kinetics of adsorption.

Pseudo-first (eqn (1)), pseudo-second (eqn (2)) and Elovich (eqn (3)) kinetic models were further used in order to understand kinetics characteristics. ${ }^{33-35}$

$$
\log \left(Q_{\mathrm{e}}-Q_{t}\right)=\log Q_{\mathrm{e}}-\frac{k_{1}}{2.303} t
$$

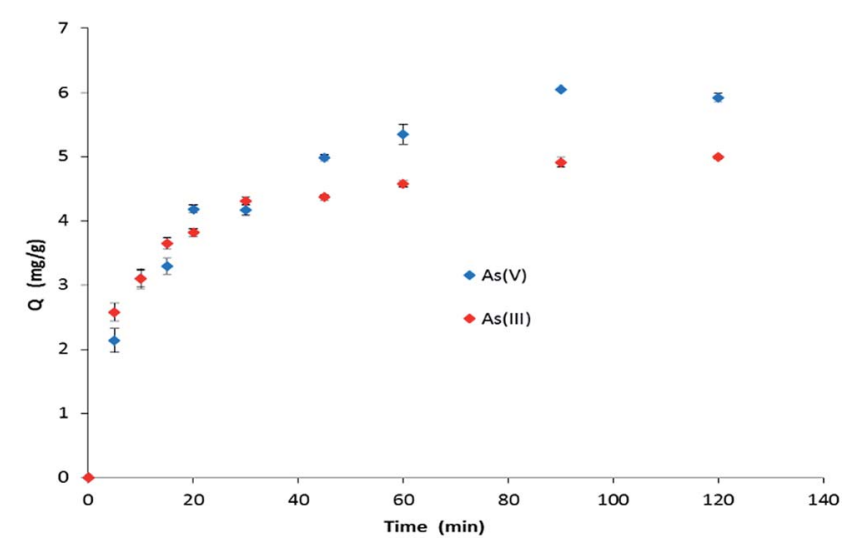

Fig. 3 Kinetic of adsorption of $\mathrm{As}(\mathrm{III})$ and $\mathrm{As}(\mathrm{V})$ on iron-oxide nanowires (initial arsenic concentration $10 \mathrm{mg} \mathrm{L}^{-1}, \mathrm{pH}=7$, dosage of iron-oxide nanowires adsorbent was $0.4 \mathrm{~g} \mathrm{~L}^{-1}$ ).

$$
\begin{gathered}
\frac{t}{Q_{t}}=\frac{1}{k_{2} Q_{\mathrm{e}}{ }^{2}}+\frac{t}{Q_{\mathrm{e}}} \\
Q_{t}=\beta \ln (\alpha \beta)+\beta \ln t
\end{gathered}
$$

where $Q_{\mathrm{e}}\left(\mathrm{mg} \mathrm{g}^{-1}\right)$ and $Q_{t}\left(\mathrm{mg} \mathrm{g}^{-1}\right)$ are adsorption capacity at equilibrium and any time $t(\mathrm{~min})$, respectively, $k_{1}\left(\mathrm{~min}^{-1}\right)$ and $k_{2}$ $\left(\mathrm{g} \mathrm{mg}^{-1} \mathrm{~min}^{-1}\right)$ are adsorption rate constants of pseudo-first and pseudo-second model, respectively, $\alpha\left(\mathrm{mg} \mathrm{g}^{-1} \mathrm{~min}^{-1}\right)$ is the initial adsorption rate and $\beta\left(\mathrm{g} \mathrm{mg}^{-1}\right)$ is the desorption constant. From the linear curve fit for the kinetic adsorption of adsorbent (Fig. S5-S7†) parameters of these kinetics models are calculated and presented in Table 1. Good linear fit, with regression coefficient $R^{2}$ values above 0.96 were obtained with all three models. The fact that all three models describe well the kinetics of the reaction goes in favor of complex mechanisms of sorption of arsenic on the iron-oxide nanowires.

While pseudo-first-order model is suitable for the description of the first 20 to $30 \mathrm{~min}$ of reaction, ${ }^{34}$ Elovich model, as an empirical model, suggests that the sorption may be controlled by multiple interaction mechanisms or processes. ${ }^{35}$ If the fractional surface coverage is lower than around 0.7 , Rudzinski and Plazinski quantitatively proved that both, Elovich and pseudosecond order model exhibit essentially identical behavior. ${ }^{36}$ The pseudo-second-order model fitted better based on the values of the regression coefficients $\left(R^{2}\right)$. As a further confirmation of agreement of the model with experimental data, indicated with good agreement between the experimentally obtained $Q_{\mathrm{e}}$ values (4.99 and $6.05 \mathrm{mg} \mathrm{g}^{-1}$ for $\mathrm{As}(\mathrm{III})$ and $\mathrm{As}(\mathrm{v})$, respectively) and $Q_{\mathrm{e}}$ values calculated from the pseudo-secondorder model (5.24 and $6.64 \mathrm{mg} \mathrm{g}^{-1}$ for As(III) and As(v), respectively), we can conclude that the overall reaction kinetics for both $\mathrm{As}(\mathrm{III})$ and As(v) were best described with pseudo-secondorder model.

\section{Effect of $\mathbf{p H}$}

One of the most important factors in the uptake of arsenic is the $\mathrm{pH}$ of the solution. Speciation of $\mathrm{As}(\mathrm{III})$ and $\mathrm{As}(\mathrm{V})$ as well as surface charge of the sorbent are dependent of the $\mathrm{pH}$ of the solution. Dominant $\mathrm{As}(\mathrm{III})$ specie at $\mathrm{pH}$ values below 9 is

Table 1 Adsorption kinetics model parameters for As(III) and As(v)

\begin{tabular}{|c|c|c|c|c|c|c|}
\hline & \multicolumn{2}{|c|}{$\begin{array}{l}\text { Pseudo-first- } \\
\text { order }\end{array}$} & \multicolumn{2}{|c|}{$\begin{array}{l}\text { Pseudo- } \\
\text { second-order }\end{array}$} & \multicolumn{2}{|c|}{ Elovich model } \\
\hline & $k_{1}$ & $Q_{\mathrm{e}}$ & $k_{2}$ & $Q_{\mathrm{e}}$ & $\alpha$ & $\beta$ \\
\hline & \multicolumn{2}{|l|}{$R^{2}$} & \multicolumn{2}{|l|}{$R^{2}$} & \multicolumn{2}{|l|}{$R^{2}$} \\
\hline \multirow[t]{2}{*}{$\operatorname{As}(\mathrm{III})$} & 0.037 & 2.64 & 0.027 & 5.24 & 8.482 & 0.767 \\
\hline & 0.963 & & 0.999 & & 0.977 & \\
\hline \multirow[t]{2}{*}{$\operatorname{As}(v)$} & 0.030 & 4.14 & 0.011 & 6.64 & 0.862 & 1.264 \\
\hline & 0.971 & & 0.995 & & 0.977 & \\
\hline
\end{tabular}
adsorption onto iron-oxide nanowires. (Experimentally obtained $Q_{e}$ value for As(III) and As(v) are 4.99 and $6.05 \mathrm{mg} \mathrm{g}^{-1}$, respectively) 
$\mathrm{H}_{3} \mathrm{AsO}_{3}$. With increasing $\mathrm{pH}$ to the $\mathrm{pH} 9.2$ the number of negative As(III) species increase and at the $\mathrm{pH}$ values greater than 9.2 the dominant form of As(III) becomes negatively charged $\mathrm{H}_{2} \mathrm{AsO}_{3}{ }^{-}$. As(v) is at the $\mathrm{pH}$ values below 2.1 present as neutral, $\mathrm{H}_{3} \mathrm{AsO}_{4}$, specie, within the $\mathrm{pH}$ range 2.1-6.7 is generally present as a negatively charged $\mathrm{H}_{2} \mathrm{AsO}_{4}{ }^{-}$while from $\mathrm{pH} 6.7$ to 11.2 $\mathrm{As}(\mathrm{v})$ is in the form of $\mathrm{HAsO}_{4}{ }^{2-}$ with double negative charge. Typically range of isoelectric point (IEP) for iron-oxides, whether they can be identified as having a particular crystal structure or not is in a pH range 7-9 (ref. 37). A determined IEP of iron-oxide nanowires is $6.4 \pm 0.1$ (Fig. $57 \dagger$ ). Below this point surface of the sorbent is positively charged while above this value negative charge dominates the surface. Effect of $\mathrm{pH}$ on sorption of $\mathrm{As}(\mathrm{III})$ and $\mathrm{As}(\mathrm{V})$ in the range 3-10 is presented in Fig. 4.

Maximum of adsorption of $\mathrm{As}(\mathrm{v})$ was at $\mathrm{pH} 3$ and with increasing $\mathrm{pH}$ we can see sharp decrease of removal efficiency until pH 6. With further increase of $\mathrm{pH}$ from 6 to 10 slight decrease of adsorption capability could be noticed. Opposite to $\operatorname{As}(\mathrm{v})$, the lowest removal of As(III) was achieved at $\mathrm{pH}$ 3. With increase of $\mathrm{pH}$ from 3 to 6 nearly $50 \%$ increase of adsorption capacity was obtained. As pH is further increased from 6 to 10 small increase of As(III) removal was achieved.

A possible explanation for the difference in behavior of As(III) and $\mathrm{As}(\mathrm{v})$ in the $\mathrm{pH}$ range from 3 to 6 may be different speciation of $\mathrm{As}(\mathrm{III})$ and $\mathrm{As}(\mathrm{v})$ species in this $\mathrm{pH}$ range. With the increase of the $\mathrm{pH}$ from 3 to 6 positive charge density of adsorbent surface decreases. This causes decrease of electrostatic attraction between the negative As(v) species and decreasing positive surface charge of the sorbent. In the case of $\mathrm{As}$ (III) in the same $\mathrm{pH}$ range comes to decrease of electrostatic repulsion between positive surface charge of adsorbent surface $\left(\mathrm{pH}_{\mathrm{IEP}}=6.4\right)$ and $\mathrm{H}^{\delta+}$ center of groups $\mathrm{OH}$ in $\mathrm{As}(\mathrm{OH})_{3}\left(\mathrm{p} K_{\mathrm{a} 1}=9.2\right)$ which could be responsible for increase of As(III) adsorption in this $\mathrm{pH}$ range. ${ }^{38}$

No noticeable change in the removal capacity of both arsenic species with increase of $\mathrm{pH}$ from 6 to 10 indicates that removal of arsenic is not governed just with electrostatic forces but could include ligand interchange between arsenic and iron-oxide nanowires.

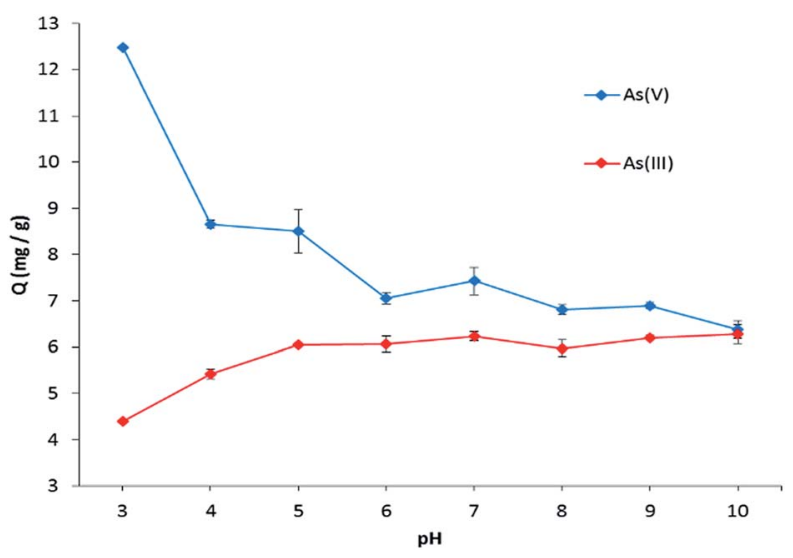

Fig. 4 Removal of $\mathrm{As}(\mathrm{III})$ and $\mathrm{As}(\mathrm{V})$ in the $\mathrm{pH}$ range of $3-10$. Initial arsenic concentration $10 \mathrm{mg} \mathrm{L}^{-1}$, dosage of iron-oxide nanowires adsorbent was $0.4 \mathrm{~g} \mathrm{~L}^{-1}$.

\section{Isotherm studies}

Freundlich and Langmuir isotherm models are two most used models for description of adsorption process. Freundlich isotherm model can be expressed by the eqn (4):

$$
Q_{\mathrm{e}}=K_{\mathrm{f}} C^{1 / n}
$$

where $K_{\mathrm{f}}\left(\mathrm{mg} \mathrm{g}^{-1}\right)\left(\mathrm{mg} \mathrm{L}^{-1}\right)^{-n}$ represents Freundlich constant related to relative adsorption capacity and $1 / n$ is dimensionless parameter who describes adsorption intensity. Freundlich equation is often considered as an empirical equation which is applicable to monolayer (chemisorption) and multilayer (van der Waals) adsorption. ${ }^{39}$

The Langmuir isotherm model can be described by the eqn (5).

$$
Q_{\mathrm{e}}=\frac{Q_{0} K_{\mathrm{L}} C_{\mathrm{e}}}{1+K_{\mathrm{L}} C_{\mathrm{e}}}
$$

where $Q_{0}\left(\mathrm{mg} \mathrm{g}^{-1}\right)$ is maximum adsorption capacity and $K_{\mathrm{L}}$ $\left(\mathrm{L} \mathrm{mg}^{-1}\right.$ ) is Langmuir adsorption constant. The Langmuir isotherm model is applicable for the monolayer adsorption on a homogeneous surface of adsorbent where interaction between neighbor surface sites is negligible. ${ }^{\mathbf{4 0}}$

The applicability of Freundlich and Langmuir models was assessed through the correlation coefficient $R^{2}$ (Fig. S8 and S9 $\dagger$ ). The parameters obtained fitting experimental data are presented in Table 2. Although for As(III) both isotherm models describe experimental data very well, slightly better regression coefficient was achieved using Freundlich than Langmuir model. Monolayer adsorption capacity of iron-oxide nanowires for As(III), obtained from the Langmuir model, was $104.5 \mathrm{mg} \mathrm{g}^{-1}$ which is amongst highest result obtained for waste material. As for As(v), adsorption data were much better fitted with Freundlich model rather than Langmuir model.

The fact that Langmuir model best describes adsorption onto homogeneous surface and Freundlich model adsorption onto heterogeneous surface sites indicates that iron-oxide nanowires have active surface sites with different affinity towards As(III) and As(v) species which results in different adsorption mechanism for $\operatorname{As}(\mathrm{III})$ and $\mathrm{As}(\mathrm{v})$, which is in agreement with kinetics and $\mathrm{pH}$ studies. The performance of iron-oxide nanowires for removal of arsenic was compared with other iron-based material (Table S1 $\dagger$ ). Adsorption capacities of $\mathrm{As}(\mathrm{III})$ and $\mathrm{As}(\mathrm{v})$ with iron-oxide nanowires are amongst highest reported for similar materials obtained from nature and very close to recently reported, synthetically made $\gamma-\mathrm{Fe}_{2} \mathrm{O}_{3}$ nanosheets. ${ }^{41}$

Table 2 Freundlich and Langmuir isotherm parameters for As(III) and

\begin{tabular}{|c|c|c|c|c|c|c|}
\hline & \multicolumn{3}{|c|}{$\begin{array}{l}\text { Freundlich isotherm } \\
\text { model }\end{array}$} & \multicolumn{3}{|c|}{ Langmuir isotherm model } \\
\hline & $K_{\mathrm{f}}$ & $n$ & $R^{2}$ & $Q_{0}$ & $K_{\mathrm{L}}$ & $R^{2}$ \\
\hline $\operatorname{As}(\mathrm{III})$ & 4.11 & 1.42 & 0.9855 & 104.53 & 0.03 & 0.9833 \\
\hline $\operatorname{As}(v)$ & 24.93 & 4.02 & 0.9558 & 48.06 & 1.93 & 0.7573 \\
\hline
\end{tabular}
$\mathrm{As}(\mathrm{v})$ adsorption onto iron-oxide nanowires 
Table 3 Effect of interference ions in the water on the removal of As(v) by the iron-oxide nanowires adsorbent

\begin{tabular}{lllll}
\hline \multirow{2}{*}{$\begin{array}{l}\text { Conc. } \\
(\mathrm{mM})\end{array}$} & \multicolumn{4}{l}{ Adsorption capacity of $\mathrm{As}(\mathrm{III})\left(\mathrm{mg} \mathrm{g}^{-1}\right)$ in the presence of ions } \\
\cline { 2 - 5 } $\mathrm{PO}_{4}{ }^{3-}$ & $\mathrm{SO}_{4}{ }^{2-}$ & $\mathrm{NO}_{3}{ }^{-}$ & $\mathrm{HCO}_{3}{ }^{-}$ \\
\hline 0.00 & $4.96 \pm 0.24$ & $4.96 \pm 0.24$ & $4.96 \pm 0.24$ & $4.96 \pm 0.24$ \\
0.10 & $4.92 \pm 0.32$ & $4.89 \pm 0.09$ & $4.64 \pm 0.53$ & $4.88 \pm 0.40$ \\
1.00 & $4.52 \pm 0.06$ & $4.60 \pm 0.20$ & $4.54 \pm 0.84$ & $4.30 \pm 0.30$ \\
10.0 & $2.36 \pm 0.65$ & $4.45 \pm 0.09$ & $4.61 \pm 0.29$ & $4.10 \pm 0.25$ \\
\hline
\end{tabular}

\section{Effect of co-existing ions on the removal of arsenic}

The interference of other ions, typically present in waters including $\mathrm{PO}_{4}{ }^{3-}, \mathrm{SO}_{4}{ }^{2-}, \mathrm{NO}_{3}{ }^{-}$and $\mathrm{HCO}_{3}{ }^{-}$on adsorption $\mathrm{As}(\mathrm{v})$ and As(III) were explored and results are summarised in Tables 3 and 4 . Results revealed that the most significant negative effect on the removal of $\mathrm{As}(\mathrm{v})$ was made by the presence of phosphate ions. Addition of $10 \mathrm{mM}$ of $\mathrm{PO}_{4}{ }^{3-}$ completely blocked adsorption of As(v) to the iron-oxide nanowires. The explanation is due to similarity of phosphate with arsenate which is in agreement with previous studies showing high affinity of iron-oxide based adsorbent for $\mathrm{PO}_{4} \cdot{ }^{3-42}$ An addition of $\mathrm{SO}_{4}{ }^{2-}$ and $\mathrm{HCO}_{3}{ }^{-}$didn't have negative effect on $\mathrm{As}(\mathrm{v})$ removal while with the addition of 1.0 and $10.0 \mathrm{mM}$ of the $\mathrm{NO}_{3}{ }^{-}$ions $\mathrm{As}(\mathrm{v})$ removal was slightly improved. As the salts used in competition study were sodium based, we assume that the cause of the favorable adsorption of $\operatorname{As}(\mathrm{v})$ was the presence of nitrate ion rather than presence of sodium cation. As for As(III), slightly decrease of arsenite adsorption can be seen for the $\mathrm{SO}_{4}{ }^{2-}, \mathrm{NO}_{3}{ }^{-}$and $\mathrm{HCO}_{3}{ }^{-}$ions while around $50 \%$ decrease in removal was achieved with the addition of $10 \mathrm{mM}$ of phosphates.

\section{FTIR study of adsorbed arsenic species}

The FTIR spectra of purified iron-oxide nanowires and spectra resulting from adsorption of $10 \mathrm{ppm}$ of As(III) and As(v) species at $\mathrm{pH} 9$ and 3, respectively are presented in Fig. S10. $\uparrow$ The bond in iron-oxide nanowires spectra at $952 \mathrm{~cm}^{-1}$ could be assigned to the $\mathrm{Fe}-\mathrm{OH}$ bending vibration. ${ }^{43}$ In the case of $\mathrm{As}(\mathrm{v})$, two different adsorption mechanisms could be responsible for attachment to the surface of iron-oxide nanowires: (1) nonspecific columbic interaction between positively charged $\mathrm{Fe}$ $\mathrm{OH}_{2}{ }^{+}$surface of adsorbent and negatively charged $\mathrm{H}_{2} \mathrm{AsO}_{4}{ }^{-}$ specie and (2) coordination of $\mathrm{H}_{2} \mathrm{AsO}_{4}{ }^{-}$specie onto surface of

Table 4 Effect of co-existing ions on the removal of As(III) by the ironoxide nanowires adsorbent

\begin{tabular}{lllll}
\hline & \multicolumn{4}{l}{ Adsorption capacity of $\mathrm{As}(\mathrm{v})\left(\mathrm{mg} \mathrm{g}^{-1}\right)$ in the presence of ions } \\
\cline { 2 - 5 } $\begin{array}{l}\text { Conc. } \\
(\mathrm{mM})\end{array}$ & $\mathrm{PO}_{4}{ }^{3-}$ & $\mathrm{SO}_{4}{ }^{2-}$ & $\mathrm{NO}_{3}{ }^{-}$ & $\mathrm{HCO}_{3}{ }^{-}$ \\
\hline 0.00 & $5.73 \pm 0.17$ & $5.73 \pm 0.17$ & $5.73 \pm 0.17$ & $5.73 \pm 0.17$ \\
0.10 & $1.26 \pm 0.05$ & $5.22 \pm 0.46$ & $5.72 \pm 0.14$ & $5.53 \pm 0.22$ \\
1.00 & $0.89 \pm 0.02$ & $5.72 \pm 0.13$ & $6.15 \pm 0.17$ & $5.71 \pm 0.38$ \\
10.0 & 0.00 & $5.82 \pm 0.14$ & $7.16 \pm 0.54$ & $5.20 \pm 0.36$
\end{tabular}

the iron-oxide nanowires. ${ }^{44}$ By comparing spectra of iron-oxide nanowires before and after adsorption of $\mathrm{As}(\mathrm{v})$ we can see a new band at $812 \mathrm{~cm}^{-1}$ and disappearance of the $952 \mathrm{~cm}^{-1}$ band. The new peak at $812 \mathrm{~cm}^{-1}$ could be attributed to the As-O vibration of $\mathrm{As}(\mathrm{v})$, which supports formation of some type of iron arsenate. ${ }^{45}$ Based on FTIR results and $\mathrm{pH}$ effect on the adsorption of $\mathrm{As}(\mathrm{v})$ we can conclude that arsenate interaction with the iron-oxide nanowires at pH 3 includes initial nonspecific columbic attraction between positively charged surface of iron-oxide nanowires and negatively charged $\mathrm{H}_{2} \mathrm{AsO}_{4}{ }^{-}$ions followed by chemical bonding and coordination of arsenate specie to the iron surface.

As for the FTIR spectra of As(III) adsorption on iron-oxide nanowires, noticeable decrease of the $952 \mathrm{~cm}^{-1}$ band indicates that interactions of $\mathrm{Fe}-\mathrm{OH}$ group with As(III) play important role but it is not dominant mechanism of As(III) removal. The possible cause for the existence of several mechanisms of adsorption of As(III) species on the surface of iron-oxide nanowires could be the fact that at $\mathrm{pH} 9, \mathrm{As}(\mathrm{III})$ exists as a neutral $\mathrm{H}_{3} \mathrm{AsO}_{3}$ and negatively charged $\mathrm{H}_{2} \mathrm{AsO}_{3}{ }^{-}$species which will interact differently with the active sites on the surface of adsorbent.

\section{Possible adsorption pathways of As(III) and As(v)}

Understanding the adsorption of arsenic by iron oxides and oxyhydroxides on a molecular level was driven by the necessity of prediction long-term fate of arsenic in aqueous sediments. Using Extended X-ray Adsorption Fine Structure (EXAFS) spectroscopy Waychunas et al. argued that arsenate adsorbs on ferrihydrate surfaces mainly as a bidentate inner-sphere complex, sharing apical oxygens of two adjacent edge-sharing Fe oxyhydroxyl octahedral, besides monodentate complexes. ${ }^{\mathbf{4 6}}$ Fendorf et al. interpreting EXAFS data further pointed out that three surface complexes: a monodentate corner sharing complex, a bidentate corner sharing and a bidentate edge sharing are possible based on degree of surface loading. ${ }^{47}$ Number of studies proved that different relative reaction rates at low and high initial As concentrations for As(v) adsorption could be related to faster formation of monodentate complexes at low surface coverages and slower formation of bidentate complexes at higher surface coverages.

What can be confusing is the fact that even using same examination techniques and similar material for removal of arsenic often conflicting results are obtained for mechanism of arsenic adsorption which are usually result of different experimental results concerning time scale, initial concentration of arsenic, $\mathrm{pH}$ of used solutions and difference in surface morphology of adsorbent.

Using results from the kinetic study combine with FTIR spectroscopic method and results of adsorption of arsenic as a function of $\mathrm{pH}$ in this work we tried to give insight into mechanism of adsorption of As(v) and As(III) onto iron-oxide nanowires. Kinetic experiments showed us that $\mathrm{As}(\mathrm{v})$ and As(III) are best described with pseudo-second order model. This model is based on the assumption that chemisorption is the rate-limiting step, implying that both arsenic species could be 
adsorbed with iron-oxide nanowires by forming chemical bonds. ${ }^{48}$ FTIR results further confirmed kinetic results identifying $\mathrm{Fe}-\mathrm{OH}$ surface group as an active adsorption sites for both As(v) and As(III). New chemical bond in the FTIR spectra of ironoxide nanowires after adsorption of As(v) can be related with the creation of iron-arsenate while significant decrease of peak signed to $\mathrm{Fe}-\mathrm{OH}$ vibration in spectra after adsorption of $\mathrm{As}$ (III) is an indicator of interaction and involvement of surface $\mathrm{OH}$ groups in the process of removal of $\mathrm{As}(\mathrm{III})$. Absence of substantial decrease of As(v) and As(III) removal at the $\mathrm{pH}$ values where both, surface of adsorbent and arsenic species are negatively charged indicates that besides electrostatic interactions and ion exchange in the $\mathrm{pH}$ below PZC of material different sorption mechanism, like surface precipitation or diffusion could be dominant.

We believe that good adsorption capability of iron-oxide nanowires owes to its unique 2D structure. In our case, high surface-to-volume ratio associated with oxide nanowires, together with microporous structure permits fast access to the surface and further diffusion of arsenic into iron-oxide nanowires. $^{49}$ Twisting 2-D wires in rope-like structure should benefit to the necessary physical strength that will prevent too high pressure drop during usage in column study, typical for nanomaterials, and enable usage of iron-oxide nanowires without need for impregnation into supporting material.

\section{Conclusions}

Iron-oxide nanowires, generated by the biofilm waste by bacteria formed in water pipelines are explored to demonstrate their applications for As removal from waters. The characterization their unique nanowire structures and chemical composition indicates their desirable properties for adsorption of heavy metals from water. SEM images of fresh biofilm revealed the presence of bacteria and confirm these structure are created from bacteria. Batch adsorption studies for arsenic removal from water using iron-oxide material indicated fast removal of arsenic species with adsorption capacity close to synthetic, specifically designed materials for arsenic removal. FTIR study and influence of $\mathrm{pH}$ on arsenic removal suggests complex mechanism of adsorption which requires further studies to be fully understood. The selectivity limitation of the adsorbent in presence of phosphate ions is observed which is typical problem for the most iron oxide based adsorbents for As removal. This biofilm obtained as a waste from cleaning the pipelines is dumped into environment causing environmental concerns and available in large quantities as a free nanoscale material. With this application it is demonstrated how to address two environmental problems in once: to use a waste material to remove considerable environmental problem such as As contamination of drinking water.

\section{Acknowledgements}

The authors thank the support of authors acknowledge the financial support provided by the Australian Research Council (FT 110100711), SA Water and the University of
Adelaide, the School of Chemical Engineering. Authors acknowledge help from Krishna Kant for purification and SEM characterizations some of bacteria nanowire samples used in this work.

\section{Notes and references}

1 P. L. Smedley and D. G. Kinniburgh, Appl. Geochem., 2002, 17, 517-568.

2 D. Mohan and C. U. Pittman Jr, J. Hazard. Mater., 2007, 142, 1-53.

3 P. R. Gentry, T. B. McDonald, D. E. Sullivan, A. M. Shipp, J. W. Yager and H. J. Clewell, Environ. Mol. Mutagen., 2010, 51, 1-14.

4 T. Zhang, M. T. Schmitt and J. L. Mumford, Carcinogenesis, 2003, 24, 1811-1817.

5 S. Tapio and B. Grosche, Mutat. Res., 2006, 612, 215-246.

6 T. Wang, T. Hsu, C. Chung, A. S. Wang, D. Bau and K. Jan, Free Radical Biol. Med., 2001, 31, 321-330.

7 M. S. Bloom, E. F. Fitzgerald, K. Kim, I. Neamtiu and E. S. Gurzau, Int. J. Hyg. Environ. Health, 2010, 213, 401-413.

8 World Health Organization, Some Drinking-Water Disinfectants and Contaminants, including Arsenic, 2004.

9 S. Ahuja, Arsenic Contamination of Groundwater: Mechanism, Analysis and Remediation, John Wiley \& Sons, Inc., Hoboken, New Jersey, 2008.

10 B. A. Manning, S. E. Fendorf, B. Bostick and D. L. Suarez, Environ. Sci. Technol., 2002, 36, 976-981.

11 C. Jing, X. Meng, E. Calvache and G. Jiang, Environ. Pollut., 2009, 157, 2514-2519.

12 K. Hristovski, A. Baumgardner and P. Westerhoff, J. Hazard. Mater., 2007, 147, 265-274.

13 K. Song, W. Kim, C.-Y. Suh, D. Shin, K.-S. Ko and K. Ha, Powder Technol., 2013, 246, 572-574.

14 R. Liu, J.-F. Liu, L.-Q. Zhang, J.-F. Sun and G.-B. Jiang, J. Mater. Chem. A, 2016, 4, 7606-7614.

15 E. Rosemblum and D. Clifford, The equilibrium arsenic capacity of activated alumina, Report EPA-600/S2-83-107, United States Environmental Protection Agency, 1984.

16 C. A. Martinson and K. J. Reddy, J. Colloid Interface Sci., 2009, 336, 406-411.

17 B. Paul, V. Parashar and A. Mishra, Environ. Sci.: Water Res. Technol., 2015, 1, 77-83.

18 I. Andjelkovic, S. Kabiri, S. Azari, M. Markovic, D. N. H. Tran and D. Losic, ACS Appl. Mater. Interfaces, 2015, 7, 9758-9766.

19 J. Perez, L. Toledo, C. H. Campos, J. Yanez, B. L. Rivas and B. F. Urbano, RSC Adv., 2016, 6, 28379-28387.

20 H. W. T. Mapoma, X. Xie, K. Pi, Y. Liu and Y. Zhu, Environ. Sci.: Processes Impacts, 2016, 18, 371-385.

21 J.-C. Hsu, C.-J. Lin, C.-H. Liao and S.-T. Chen, J. Hazard. Mater., 2008, 153, 817-826.

22 L. S. Zhong, J. S. Hu, H. P. Liang, A. M. Cao, W. G. Song and L. J. Wan, Adv. Mater., 2006, 18, 2426-2431.

23 F. Z. Mou, J. G. Guan, Z. D. Sun, W. D. Shi and X. A. Fan, J. Mater. Chem., 2011, 21, 5414-5421.

24 B. Wang, H. Wu, L. Yu, R. Xu, T.-T. Lim and X. W. Lou, Adv. Mater., 2012, 24, 1111-1116. 
25 S. Aredes, B. Klein and M. Pawlik, J. Cleaner Prod., 2013, 60, 71-76.

26 E. D. Melton, E. D. Swanner, S. Behrens, C. Shmidt and A. Kappler, Nat. Rev. Microbiol., 2014, 12, 797-808.

27 D. Emerson, et al., Annu. Rev. Microbiol., 2010, 64, 561-583. 28 T. Suzuki, et al., Appl. Environ. Microbiol., 2011, 2877-2881.

29 L. Wang, T. Kumeria, A. Santos, P. Forward, M. F. Lambert and D. Losic, ACS Appl. Mater. Interfaces, 2016, 8(31), 20110-20119.

30 T. Kumeria, S. Maher, Y. Wang, G. Kaur, L. Wang, M. Erkelens, P. Forward, M. Lambert, A. Evdokiuo and D. Losic, Biomacromolecules, 2016, 17(8), 2726-2736.

31 S. Dixit and J. G. Hering, Environ. Sci. Technol., 2003, 37, 4182-4189.

32 IUPAC Recommendations, Pure Appl. Chem., 1994, 66, 17391758.

33 M. Asadullah, I. Jahan, M. B. Ahmed, P. Adawiyah, N. H. Malek and M. S. Rahman, J. Ind. Eng. Chem., 2014, 20, 887-896.

34 G. McKay, Y. C. Ho and J. C. Y. Ng, Sep. Purif. Rev., 1999, 28, 87-125.

35 D. L. Sparks, Kinetics and mechanisms of chemical reactions at the soil mineral/water surface, Soil Physical Chemistry, CRC Press LLC, Bocca Raton, FL, 2nd edn, 1999.

36 W. Rudzinski and W. Plazinski, Adsorption, 2009, 15, 181192.
37 X. Guo and F. Chen, Environ. Sci. Technol., 2005, 39, 68086818.

38 B. Manna and U. C. Ghosh, J. Hazard. Mater., 2007, 144, 522531.

39 C. Yang, J. Colloid Interface Sci., 1998, 208, 379-387.

40 Y. Liu, Colloids Surf., A, 2006, 276, 34-36.

41 R. Liu, J.-F. Liu, L.-Q. Zhang, J.-F. Sun and G.-B. Jiang, J. Mater. Chem. A, 2016, 4, 7606-7614.

42 W. Xu, J. Wang, L. Wang, G. Sheng, J. Liu, H. Yu and X.-J. Huang, J. Hazard. Mater., 2013, 260, 498-507.

43 I. Carabante, M. Grahn, A. Holmgren, J. Kumpiene and J. Hedlund, Colloids Surf., A, 2009, 346, 106-113.

44 C. Escudero, N. Fiol, I. Villaescusa and J.-C. Bollinger, J. Hazard. Mater., 2009, 164, 533-541.

45 P.-Y. Wu, Y.-P. Yiang, Q.-Y. Zhang, Y. Jia, D.-Y. Peng and W. Xu, New J. Chem., 2016, 40, 2878-2885.

46 G. A. Waychunas, B. A. Rea, C. C. Fuller and J. A. Davis, Geochim. Cosmochim. Acta, 1993, 57, 2251-2269.

47 S. Fendorf, M. J. Eick, P. Grossl and D. L. Sparks, Environ. Sci. Technol., 1997, 31, 315-320.

48 P. S. Kumar, R. Q. Flores, C. Sjösedt and L. Önnby, J. Hazard. Mater., 2016, 302, 166-174.

49 X. Jiang, Y. Wang, T. Herricks and Y. Xia, J. Mater. Chem., 2004, 14, 695-703. 